\title{
Effects of 16-Weeks Traditional Game Intervention Increase Static Balance of Deaf Students in SLB-B Yayasan Pendidikan Tunas Bangsa Malang
}

\author{
Slamet Raharjo ${ }^{\mathrm{a}^{*},}$, Heru Kurniawan ${ }^{\mathrm{a}}$ \\ *Corresponding Author: Slamet Raharjo, E-Mail: slamet.raharjo.fik@um.ac.id \\ ${ }^{a}$ Department of Sport Science, Faculty of Sport Science, Universitas Negeri Malang, Malang, Indonesia
}

\begin{abstract}
The purpose of the study was to find out the effects of traditional game training on improving the static balance of deaf students at the SLB-B Yayasan Pendidikan Tunas Bangsa Malang. This type of research was pre-experimental, using the design of two random pretest-posttest groups. Sampling in this study using purposive sampling techniques as many as 16 children in SLBB Yayasan Pendidikan Tunas Bangsa Malang, then divided into two groups: GSTG ( $\mathrm{n}=8$; Gobak Sodor Traditional Game), and ETG ( $\mathrm{n}=8$; Engklek Traditional Game). The first group was given treatment with the traditional game of gobak sodor, and the second group was given the traditional engklek game with a frequency of 3 times/week for 16 weeks. Static balance measurements were carried out pre-exercise and 16 weeks post-exercise using the Stork Balance Stand Test tool. The data analysis technique used a different test Paired Sample T-Test and Independent Samples T-Test with SPSS version 25 software. The results obtained an average static balance between pre-exercise and post-exercise at GSTG $(12.13 \pm 1.96$ vs. $18.75 \pm 2.25$ seconds, $(\mathrm{p} \leq 0.001))$ and ETG $(13.38 \pm 1.60$ vs. $30.38 \pm 2.50$ seconds, $(\mathrm{p} \leq 0.001))$. Based on the results of the study, it was concluded that gobak sodor and engklek traditional game had a significant effect on increasing static balance in SLB-B Yayasan Pendidikan Tunas Bangsa Malang. However, engklek traditional game is more effective in improving static balance compared to the gobak sodor traditional game.
\end{abstract}

Keyword: Traditional game, gobak sodor, engklek, static balance, deaf

\section{Introduction}

A healthy and intact physical condition becomes everyone's hope. But, it's different for people with disabilities who have limitations on physical, mental, intellectual, or sensory (Duffy \& Kelly, 2017). Language deprivation and poor health outcomes in the deaf population are risks that cannot be addressed solely by hearing intervention (Wilkinson \& Morford, 2020). Over 5\% of the world's population or 430 million people require rehabilitation to address their 'disabling' hearing loss (432 million adults and 34 million children) and it is estimated that by 2050 over 700 million people or one in every ten people will have disabling hearing loss (WHO, 2021). Disorders to dysfunction of the auditory organs for people with deaf disabilities due to accidents or congenital disorders cause limitation in carrying out various activities, especially physical activity (Aslan, 2019). Physical inactivity leads to unhealthy lifestyle changes, such as irregular diets and sedentary lifestyles (Nichols et al., 2019). Poor physical condition results in health problems, such as being overweight, decreased muscle mass, and decreased mental health (Lennon \&Verheyden, 2018). When it comes, it will certainly lower health status and decrease physical fitness for daily activities (Taylor et al., 2018).

Deaf or hearing loss is caused by issues in important organs, namely the vestibular. Vestibular has been linked to motor skills, that is body balance (Ebrahimi et al., 2016). A study conducted by Wong et al. (2013), shows that children with hearing loss have poor performance in body balance. Maes et al. (2014), also conducted a study on deaf children with vestibular disorders to get the result that deaf children score worse balance tests compared to normal children. 
Body balance is key to motor movement because body balance involves various movements in each segment of the body supported by the skeletal muscle system and fulcrum field (Chang et al., 2016). Body balance is bending by visual, vestibular, and somatosensory (Volery et al., 2017). In addition, balance is one of the biometric components that can keep the body stable with every static and dynamic movement. Regular exercise can affect health, especially for people with disabilities (Nemček \& Mókušová, 2020). Charles et al. (2017), agree that the benefit of traditional games is good for children's motor skills. Hakim et al. (2013), motor skills or static balance will not be able to develop without the maturity of motor control in the individual, such as doing practice for it. Until now, there are no studies to determine the dose of exercise to improve motor movement or body balance in people with deafness.

Based before, researchers wanted to uncover in this study the effect of traditional game training on improving the static balance of deaf students at SLB-B Yayasan Pendidikan Tunas Bangsa Malang.

\section{Materials and Methods}

The study is pre-experimental with the randomized pretest-posttest two-group design (Sugiyono, 2017). 16 students participated, which are male and aged 8-11 years. Students were randomly divided into two groups, namely: GSTG ( $\mathrm{n}=8$; Gobak Sodor Traditional Game), and ETG ( $\mathrm{n}=8$; Engklek Traditional Game). All of the subject's parents obtained information about this research through writing and orally. Subjects' parents filled out and signed informed consent before participating in the study.

The traditional game of gobak sodor and engklek is played at the field SLB-B Yayasan Pendidikan Tunas Bangsa Malang. The traditional games of gobak sodor and engklek are performed 3 times/week for 6 weeks. The traditional games of gobak sodor and engklek are applied and supervised by professional officers from the Department of Sports Science, Faculty of Sports Science, State University of Malang and accompanied by a Sports Teacher from SLB-B Yayasan Pendidikan Tunas Bangsa Malang.

Before the traditional games of gobak sodor and engklek were applied, subjects were asked to undergo a static balance test using the Stork Balance Stand Test. Subjects stood on one leg with hands in front of the chest for a maximum of 2 minutes. Total standing time was recorded. The test ratings are shown in Table 1 below (Rahman et al., 2017). Static balance measurements were carried out twice, that is before exercise and 16 weeks after exercise.

Table 1. Stork Balance Stand Test Score

\begin{tabular}{cc}
\hline Rating & Score (seconds) \\
\hline Excellent & $>50$ \\
Good & $40-50$ \\
Average & $25-39$ \\
Fair & $10-24$ \\
Poor & $<10$ \\
\hline
\end{tabular}

Source: Rahman et al. (2017:496) 
The data analysis used SPSS version 25 software. Shapiro-Wilk was used to test for normality, while Paired Sample T-Test and Independent Samples T-Test were used to test differences between groups. All data are shown with mean \pm Standard Deviation (SD). All statistical analyzes used a significant level $(\mathrm{p} \leq 0.01)$.

\section{Results}

The results of the static balance between pre-exercise vs post-exercise in the gobak sodor and engklek groups are presented in Figure 1.

GSTG

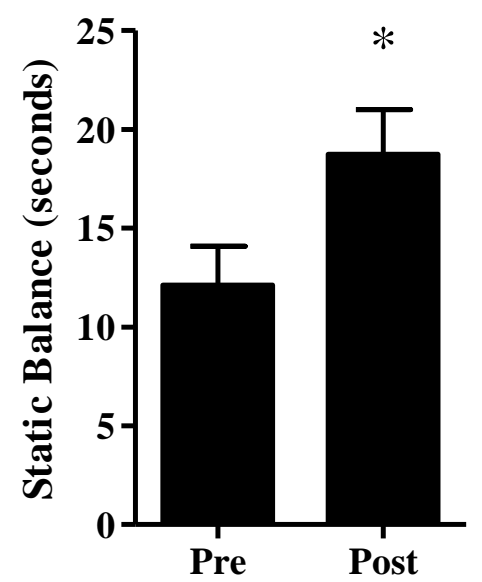

\section{ETG}

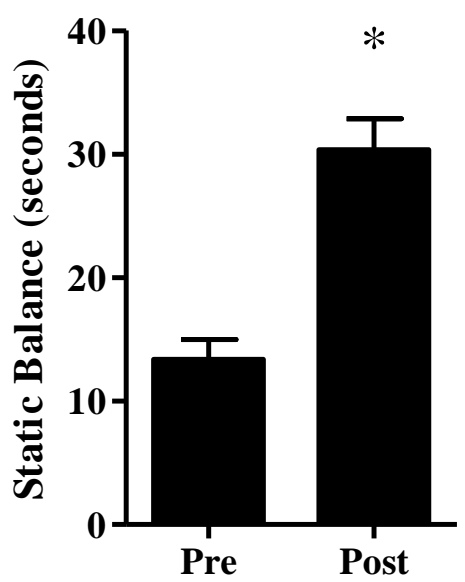

Figure 1. mean of static balance between pre-exercise vs. post-exercise in each group

Note: GSTG: Gobak sodor traditional game; ETG: Engklek traditional game. $\left({ }^{*}\right)$ Signifikan vs. pre-exercise $(\mathrm{p} \leq 0.001)$

Based on Figure 1 the results of the descriptive analysis show that there is an increase in the mean of static balance between pre-exercise and post-exercise in each group. The results of the different Paired Sample T-Test showed that there was a significant difference in the mean increase in static balance between pre-exercise and post-exercise on GSTG $(12.13 \pm 1.96$ vs. $18.75 \pm 2.25$ seconds, $(\mathrm{p} \leq 0.001))$ and ETG $(13.38 \pm 1.60$ vs. $30.38 \pm 2.50$ seconds, $(\mathrm{p} \leq 0.001))$.

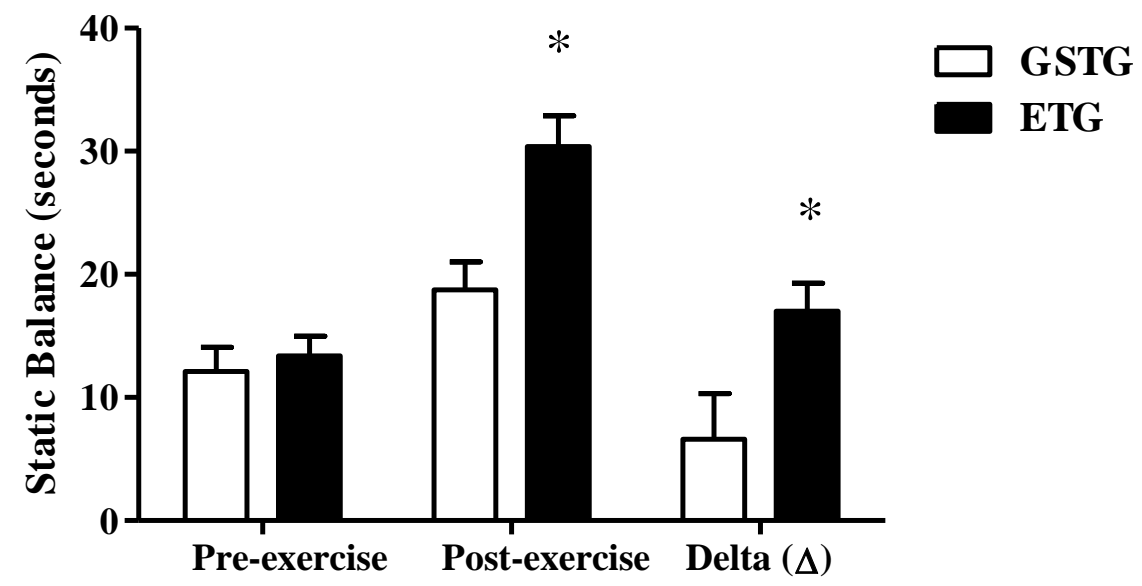

Figure 2. Mean of static balance between GSTG vs. ETG

Note: GSTG: Gobak sodor traditional game; ETG: Engklek traditional game. (*) Signifikan vs. GSTG (p $\leq 0.001)$ 
Based on Figure 2, the results of the descriptive analysis show that the mean of pre-exercise static balance between GSTS and ETG tends to be the same, while the mean increase in post-exercise static balance and delta $(\Delta)$ on ETG is higher than that of GSTS. The results of the Independent Samples T-Test difference test showed that there was no significant difference in the mean of pre-exercise static balance between GSTS and ETG $(\mathrm{p} \geq 0.001)$, while the mean increase in post-exercise static balance and delta $(\Delta)$ between GSTS and ETG ETG showed a significant difference $(\mathrm{p} \leq 0.001)$.

\section{Discussion}

The study aims to analyze the influence of gobak sodor and engklek traditional game improving the static balance of deaf students at SLB-B Yayasan Pendidikan Tunas Bangsa Malang. The results of this study indicate that the traditional game of gobak sodor and engklek significantly improves the static balance of deaf students at SLB-B Yayasan Pendidikan Tunas Bangsa Malang (Figure 1). However, the traditional engklek game is more effective in improving static balance compared to the traditional gobak sodor game (Figure 2). This result was reinforced by Rajendran et al. (2013), suggest that exercise programs that enhance the visual-motor and somatosensory abilities that enable substitution are more effective in improving the vestibular related deficits in children with hearing impairment. Effgen (1981), shows that the length of time that children in the experimental group could stand on one leg increased significantly.

The traditional game of engklek is also called Hopscotch which means Hop (jump or jump) and scotch (lines that exist in the traditional game of engklek). Originally the traditional game of engklek was used to train the speed, strength, and stamina of the Roman army while carrying war equipment. While in Indonesia, the traditional game engklek is known as a folk game that is close to the world of children. The game is done through a pleasant atmosphere, the activities in this game are walking, jumping on one leg or two feet (Hasibuan \& Jannah, 2018). Al Attar \& Alshehri (2019), the implementation of single-leg stance (SLS) and jumping exercise (JE) can improve postural stability among female college students, leading to reduce injury risk in that population. Meanwhile, gobak sodor according to Putra \& Hasanah (2018), gobak sodor is a game that is played in groups, consisting of 3-6 people. Apart from the point of view of motion mechanics, traditional engklek (individual) games involve muscle contractions with more frequency than gobak sodor (teams). The involvement of muscle contractions can induce the endocrine system to be involved, especially in increasing the ability of muscles as an active tool of movement that carries out static balance of the body and nerves as the body's control center.

Children at the age of 6-12 years are the initial training period, whereas at the age of 8-11 years learning should be fun and an effort to develop physical movement abilities (Sidi, 2010). Training activities in the engklek game that are carried out in a planned, regular, and balanced time can lead to a physiological adaptation in the organs of the body. Sugiharto (2014) suggested that 6-8 weeks of training had a very good effect on the body, in addition to the use of the frequency of exercise carried out for 3 meetings in one week has benefits for developing strength and endurance. In addition, sports activities (jogging, running, and playing) within 20-30 minutes will improve physical fitness, especially in leg muscle strength which will affect the level of balance (Hita, 2020). According to Mardayani et al. (2016), the application of traditional games has elements of providing fun which aims to train motor skills, balance, and dexterity. In a previous study by Pujiati \& Wijayanto (2019) entitled "The Effect of Traditional Engklek Games on the Balance of Children aged 4-6 Years in Kindergarten Pertiwi" stated 
that giving traditional engklek games has a significant effect on the balance of children aged 4-6 years. So from the relevant study results that the traditional engklek game exercise can be used to train static body balance.

\section{Conclusions}

Based on the results of the study, it was concluded that the traditional games of gobak sodor and engklek which were performed $3 x /$ week for 16 weeks had a significant effect on increasing static balance in SLB-B Yayasan Pendidikan Tunas Bangsa Malang. However, the engklek traditional game is more effective in improving static balance compared to the gobak sodor game traditional.

\section{Reference}

Al Attar, Wesam \& Alshehri, Mansour Abdullah. (2019). The effectiveness of single-leg stance and jumping exercises on postural stability in female college students: a randomized controlled trial. Journal of Science and Medicine in Sport. 22. S75-S76. https://doi.org/10.1016/j.jsams.2019.08.073.

Aslan, S. 2019. Perceived Stress Level and Sports Participation in Deaf Adolescents and Young Adults. Journal of Education and Training Studies, 7(3), 197-201. https://doi.org/10.11114/jets.v7i3.3974.

Charles, A. G., Abdullah, M. R. \& Musa, R. M. 2017. The Effect of Traditional Games Intervention Program In The Enhancement School-Age Children's Motor Skills: A Preliminary Study. 6(2), 157-169.

Duffy, R. M., \& Kelly, B. D. (2017). Rights, laws, and tensions: A comparative analysis of the Convention on the Rights of Persons with Disabilities and the WHO Resource Book on Mental Health, Human Rights and Legislation. International journal of law and psychiatry, 54, 26-35. https://doi.org/10.1016/j.ijlp.2017.07.003.

Ebrahimi, A. A., Movallali, G., Jamshidi, A. A., Haghgoo, H. A., \& Rahgozar, M. (2016). Balance Performance of Deaf Children With and Without Cochlear Implants. Acta Medica Iranica, 54(11), 737-742.

Effgen S. K. (1981). Effect of an exercise program on the static balance of deaf children. Physical therapy, 61(6), 873-877. https://doi.org/10.1093/ptj/61.6.873.

Hakim, A.R., Soegiyanto., \& Soekardi. 2013. The Effect of Early Age and Balance Training on Gross Motor Skills in Lower Grade Mentally Impaired Children Able to Educate in Extraordinary Schools. Journal Of Physical Education and Sport, 2(1), 201-204. Available: https://journal.unnes.ac.id/sju/index.php/jpes.

Hasibuan, R. \& Jannah, M. 2018. Traditional Game “Engklek” and Young Children's Gross Motor Ability. 169(Icece 2017), 237-239. https://doi.org/10.2991/icece-17.2018.61.

Hita, I. P. A. D. (2020). The Effectiveness of Aerobic and Anaerobic Exercise Methods To Reduce Overweight and Obesity Levels. Penjakora Journal, 7(2), 135-142.

Lennon, S., Ramdharry, G. and Verheyden, G. 2018. Physical Management for Neurological Conditions. E-Book. Elsevier Health Sciences.

Maes, Leen, Alexandra, D.K, Hilde, V. W., Dhooge, Ingeborg. (2014). Association Between Vestibular Function and Motor Performance and Hearing-Impaired Children. Belgium. Otologi \& Neurotologi, Inc.

Mardayani, K. T., Mahadewi, L. P. P. \& Magta, M. (2016). The Application of Traditional Engklek Games to Improve Gross Motor Ability of Group B in Widhya Laksmi' PAUD, Journal of Early Childhood Education, 4(2), 1-10. doi: http://dx.doi.org/10.23887/paud.v4i3.8548. 
Nemček, D. \& Mókušová, O. (2020). Position of sport in subjective quality of life of deaf people with different sport participation levels. Physical Culture and Sport. Studies and Research,87(1), 1-8. https://doi.org/10.2478/pcssr-2020-0014.

Nichols, C., Block, M. E., Bishop, J. C., \& McIntire, B. (2019). Physical activity in young adults with autism spectrum disorder: Parental perceptions of barriers and facilitators. Autism: the international journal of research and practice, 23(6), 1398-1407. https://doi.org/10.1177/1362361318810221.

Pujiati, I. D., \& Wijianto, S. S. T. (2019). The Effect of Traditional Engklek Games on the Balance of 4-6 Years Old Children in TK Pertiwi 1 (Doctoral dissertation, Universitas Muhammadiyah Surakarta).

Rahman, K.A., Azaman, A., Latip, H.F.M., Dzahir, M.A.M., Balakrishnan, M. (2017). Comparison of tibialis anterior and gastrocnemius muscles activation on balance training devices and hoverboard. Malaysian Journal of Fundamental and Applied Sciences. Special Issue on Medical Device and Technology, 495-500.

Rajendran, V., Roy, F. G., Jeevanantham, D. (2013). Effect of exercise intervention on vestibular related impairments in hearing-impaired children. Alexandria Journal of Medicine, 49(1), 7-12. https://doi.org/10.1016/j.ajme.2012.10.001.

Sidi, B.D. 2010. The Benefits of Guided Game Sports in the Character Building of Pre-Adolescents. Jurnal Akrab, 1(3), 16-29.

Sugiharto. (2014). Sports Physiology. 2014 th edn. Malang: Universitas Negeri Malang.

Taylor, S. L., Noonan, R. J., Knowles, Z. R., Owen, M. B., McGrane, B., Curry, W. B., \& Fairclough, S. J. (2018). Evaluation of a Pilot School-Based Physical Activity Clustered Randomised Controlled Trial-Active Schools: Skelmersdale. International journal of environmental research and public health, 15(5), 1011. https://doi.org/10.3390/ijerph15051011.

Volery, S., Singh, N., de Bruin, E. D., List, R., Jaeggi, M. M., Mattli Baur, B., \& Lorenzetti, S. (2017). Traditional balance and slackline training are associated with task-specific adaptations as assessed with sensorimotor tests. European journal of sports science, 17(7), 838-846. https://doi.org/10.1080/17461391.2017.1317833.

Wilkinson, E., \& Morford, J. P. (2020). How Bilingualism Contributes to Healthy Development in Deaf Children: A Public Health Perspective. Maternal and child health journal, 24(11), 1330-1338. https://doi.org/10.1007/s10995-020-02976-6.

World Health Organization. (2021, April 1). Deafness and hearing loss. Retrieved from www. who.int: https://www.who.int/news-room/fact-sheets/detail/deafness-and-hearing-loss.

Wong, T. P. S., Leung, E.Y.W., mPhil, Poon, C.Y.C., Leung, C.Y.F., \& Lau, B.P.H. 2013. Balance Performance in Children with unilateral and bilateral severe-to-profound-grade hearing impairment. Hong Kong Physiotherapy Journal, 31(2), 81-87. https://doi.org/10.1016/j.hkpj.2013.07.001.

Yi-Chun Chang, Ching-Ting Hsu, Wei-Hua Ho, \& Yueh-Tung Kuo. (2016). The Effect of Static Balance Enhance by Table Tennis Training Intervening on Deaf Children. https://doi.org/10.5281/zenodo.1125573. 